\title{
Dampak Sistem Pengamanan Data di Layanan OVO terhadap Peningkatan Penggunanya
}

\author{
Alvin Subrata, Andriany Yutanto, Budi Altati Sulastri Simangunsong, \\ Ernest Eliot Hanom Simatupang, Henri Widodo
}

\author{
School of Business and Economics Universitas Prasetiya Mulya \\ JL. RA. Kartini (TB Simatupang), Cilandak Barat Jakarta Selatan, Jakarta 12430 Indonesia
}

Corresponding Author: 15131810038@ student.prasetiyamulya.ac.id;

\begin{abstract}
Abstrak
Sistem Pembayaran Elektronik (SPE) telah meningkatkan kualitas hidup individu dengan memberikan kemudahan bertransaksi online. Kami membahas sistem pembayaran OVO sebagai aplikasi selular yang paling banyak digunakan di Jakarta pada khususnya. Penelitian ini menguji dampak sistem pengamanan data pada layanan OVO terhadap peningkatan penggunanya. Dari 262 sampel responden yang dianalisa; hasilnya menunjukkan bahwa baik persepsi keamanan dan kepercayaan memiliki pengaruh signifikan terhadap penggunaan OVO. Perlindungan teknis dan pengalaman masa lalu menjadi penentu umum dari rasa aman dan kepercayaan yang dirasakan. Implikasi manajerial dari temuan dibahas secara ringan dalam keterbatasan penelitian dan saran untuk penelitian lebih lanjut.
\end{abstract}

Kata kunci: Persepsi kepercayaan; keamanan; pengalaman masa lalu; Sistem Pembayaran Elektronik (SPE);

\section{Abstract}

Electronic Payment Systems (EPS) provides an increase in the quality of life of individuals by providing the convenience of online transactions. We discuss OVO payment system as the most widely used mobile application in Jakarta in particular. This study considers the impact of data security system towards the use of OVO. We analyzed 262 samples of respondents. The results shows a good perception of security and a significant interest in the use of OVO. Technical protection and past experience are common concern of the security and trust received. Managerial implications of the findings discussed in the research proposal and suggestions for further research.

Keywords: Perception of trust; security; past experience; electronic payment system (EPS) 


\section{Pendahuluan}

Perkembangan teknologi khususnya dalam Sistem Pembayaran Elektronik (SPE) terus mengalami kenaikan baik dari sisi peningkatan nilainya maupun volume transaki dikarenakan adanya dukungan dari teknologi komunikasi dan informatika yang semakin berkembang. Berbagai layanan seperti ini sedang tumbuh subur di Indonesia dan tidak dipungkiri SPE ini telah menjadi bagian dalam setiap aktifitas transaksional harian kita. Penyediaan informasi yang akurat, manfaat dan resiko yang jelas sangatlah diperlukan untuk diketahui oleh para konsumennya dimana diharapkan dapat mengurangi resiko yang mungkin timbul dalam penggunaan layanan SPE.

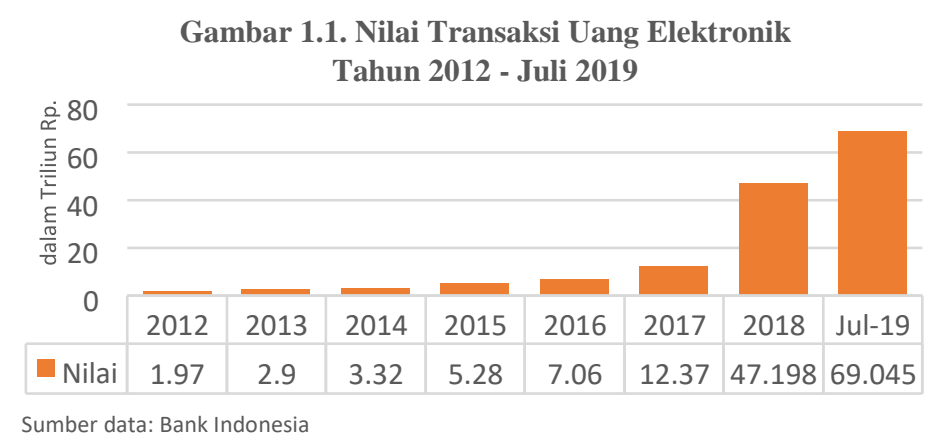

Berdasarkan data Bank Indonesia, dapat dilihat bahwa tren penggunaan SPE terus meningkat dimana sejak awal 2019 hingga Juli 2019, nilai transaksi uang elektronik yang tercatat telah mencapai Rp 69 triliun (Statistik Transaksi Uang Elektronik, Bank Indonesia, Jakarta 2019). Berdasarkan hasil survei Snapcart yang dilakukan pada Mei 2019 terhadap 1800 responden di 6 kota mengenai perilaku konsumen dalam bertransaksi dengan aplikasi pembayaran elektronik, disebutkan tiga nama yang mendominasi pasar saat ini. Yang pertama ada OVO, yang dipilih oleh 58 persen responden. GO-PAY berada di urutan kedua yang dipilih oleh 23 persen responden. Kemudian ada nama DANA (6 persen) dan LinkAja (1 persen). Sementara sisa 11 persen responden lainnya memilih layanan pembayaran elektronik seperti Flazz, Brizzi, Mandiri e-Money yang merupakan layanan dari institusi perbankan. Techniasia

Website, Karisma G. 2019, Riset Snapcart Menambah Panjang Peta Persaingan Fintech Indonesia, $\quad$ https://id.techinasia.com/snapcart-dompet-digital-indonesia$\underline{2019}$, (2 Agustus 2019)

Penulisan penelitian ini juga didasarkan permasalahan yang timbul dari layanan SPE, dimana berdasarkan hasil riset mandiri sebelumnya yang dilakukan oleh Tirto bekerjasama dengan Jakpat pada 11 Oktober 2017 terhadap 1.002 responden untuk mengetahui rasa 
khawatir masyarakat di wilayah Jabodetabek dalam penggunaan pembayaran elektronik, menyimpulkan bahwa responden mengetahui jika data mereka otomatis terekam, dan ternyata ada 50,90 persen yang "khawatir" perihal privasi dan adanya pencurian data pribadi yang dijual kepada pihakpihak lain. Tirto, Purnamasari D., 2017, 50,90\% Masyarakat Khawatirkan Penggunaan Data e-

Money, https://tirto.id/cy41. (2 Agustus 2019)

Penelitian ini adalah untuk menguji apakah sistem pengamanan data dan pengalaman masa lalu para pengguna OVO memiliki implikasi terhadap meningkatnya pengguna OVO, yang akan ditinjau berdasarkan penelitian sebelumnya tentang masalah keamanan dan kepercayaan pengguna SPE. Kerangka kerja konseptual disajikan dengan hipotesis yang dikembangkan. Selanjutnya, metodologi dan hasil penelitian dibahas. Dan akhirnya, kesimpulan dan implikasi penelitian ini yang disajikan di bagian terakhir makalah.

\section{Tinjauan Pustaka \& Pengembangan Hipotesa}

Penggunaan ekstensif dan komersialisasi Internet telah menciptakan elektronik yang dinamis dunia perdagangan. Ravi Kalakota (1997) Perdagangan elektronik adalah aktivitas belanja online dengan menggunakan jaringan internet serta cara transaksinya melalui transfer uang secara digital. SPE digunakan untuk penyelesaian perdagangan elektronik transaksi dan telah didefinisikan sebagai 'sistem pembayaran yang memfasilitasi elektronik aman transaksi perdagangan antara organisasi dan individu. Linck, Pousttchi, dan Wiedemann (2006) menyatakan bahwa untuk bisnis yang beroperasi secara elektronik, salah satu penentu keberhasilan yang paling penting adalah digunakannya SPE. Akibatnya, SPE telah menarik banyak perhatian oleh para peneliti dan praktisi sejak kemunculan perdagangan elektronik.

Meskipun SPE telah meningkat secara signifikan selama dekade terakhir, masalah keamanan dan kepercayaannya masih mengkhawatirkan penggunanya di tahun 2000-an, dan kekhawatiran seperti itu masih ada (Shon \& Swatman 1998). Dalam konteks SPE, keamanan dan kepercayaan sangat penting; keamanan telah didefinisikan sebagai 'serangkaian prosedur, mekanisme dan program komputer untuk diautentikasi sumber informasi dan menjamin integritas dan privasi informasi tersebut (data) untuk abstain keadaan ini untuk mengarah pada kesulitan (ekonomi) data atau jaringan sumber daya '(Tsiakis \& Sthephanides 2005, hal. 10). Kepercayaan didefinisikan sebagai bentuk kepercayaan pada seorang mitra secara keseluruhan dan keandalan dan integritasnya (Moorman, Deshpande, \& Zaltman 1993). Menurut Reichheld dan Schefter (2000), kepercayaan sangat penting dalam hubungan transaksional, terutama yang mengandung risiko tinggi seperti transaksi online. Dengan kata lain, 


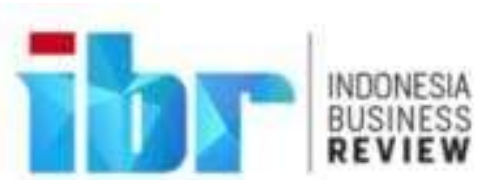

kepercayaan sama pentingnya dengan keamanan untuk kesuksesan SPE. Jadi, mengidentifikasi dan memahami faktor-faktor yang mempengaruhi kepercayaan dan keamanan adalah penting bagi para praktisi yang berurusan dengan SPE.

Kurangnya rasa aman dan kepercayaan yang dirasakan telah diidentifikasi sebagai salah satu faktor paling vital memperlambat perkembangan e-commerce. Namun, e-commerce tidak memiliki dua elemen wajib ini pada dasarnya; begitulah permasalahan untuk membangun dan mempertahankan kepercayaan untuk sistem ini. Inilah sebabnya mengapa itu terutama penting untuk memiliki SPE yang aman dan memeriksa perlindungan teknis yang dikembangkan untuk mengurangi risiko e-commerce sebelum menangani masalah kepercayaan pengguna.

Penelitian sebelumnya telah menunjukkan bahwa kurangnya kontak manusia atau hubungan sosial selama proses pembayaran elektronik menciptakan ancaman bagi keamanan SPE. Menurut peneliti seperti Eastlick, Lotz, dan Warrington (2006), kepercayaan dan masalah privasi adalah dua alasan khusus yang mencegah individu terlibat dalam transaksi ecommerce. Demikian juga, temuan survei oleh Gartner Group (2001) menyatakan bahwa ketika berbelanja online, masalah kepercayaan dan privasi adalah perhatian utama $95 \%$ dari peserta (Gartner Group 2001). Dengan demikian, keamanan sangat penting untuk penggunaan SPE. Sebelum yang lainnya, yang pertama dan terutama SPE harus memberikan keamanan bagi penggunanya (Kim et al., 2010; Linck et al., 2006; Tsiakis \& Sthephanides 2005).

Literatur yang ada terutama berfokus pada keamanan dan kepercayaan pada SPE dari perspektif penyedia layanan (Linck et al., 2006) dan tidak cukup perhatian telah diberikan kepada konsumen persepsi keamanan dan kepercayaan. Sebagai akibatnya, penelitian teoritis dan empiris kurang dalam bidang yang sangat penting ini. Pengecualian penting adalah studi tentang Kim et al. (2010). Mereka penelitian meneliti faktor-faktor penentu penggunaan SPE konsumen. Mereka telah menyimpulkan itu baik keamanan dan kepercayaan yang dirasakan memiliki dampak positif dan signifikan pada penggunaan SPE. Dalam urutan untuk mengatasi kekurangan yang disebutkan di atas dalam literatur, penelitian ini meneliti keamanan dan kepercayaan pada SPE dari sudut pandang konsumen dalam ekonomi pulau kecil (Utara) Siprus). Selain itu, faktor-faktor yang memengaruhi persepsi kepercayaan dan keamanan konsumen juga telah diperiksa untuk memberikan pemahaman yang lebih dalam tentang fenomena penelitian.

Dengan munculnya perdagangan elektronik, SPE menjadi salah satu moneter paling penting dan praktis alat transaksi untuk konsumen dan bisnis. Bersamaan, perantara baru seperti itu karena PayPal berhasil memenuhi kebutuhan baru dan baru dari pengguna perdagangan elektronik (yaitu konsumen dan pedagang) (Dahlberg, Dahlberg, \& Nyström 
2008); seperti pembayaran elektronik yang merupakan persyaratan penting untuk menyelesaikan transaksi perdagangan elektronik.

Menurut Kim et al. (2010), pembayaran elektronik adalah transfer nilai elektronik dari pembayar ke penerima pembayaran melalui mekanisme elektronik. Layanan pembayaran elektronik membantu dan memungkinkan individu untuk mengelola transaksi keuangan mereka dari jarak jauh (Lim 2008). Menurut Tsiakis dan Sthephanides (2005), SPE mencapai dua hal khususnya: (a) persaingan yang ada kerangka kerja pembayaran dari dunia nyata dan / atau (b) sistematisasi cara baru untukmelakukan transaksi pembayaran (Tsiakis \& Sthephanides 2005).

SPE dapat diklasifikasikan ke dalam lima kategori (Kim et al., 2010).

Kategori-kategori ini adalah :

Uang tunai elektronik: Uang tunai elektronik adalah metode pembayaran di mana identifikasi tertentu nomor dikaitkan dengan jumlah uang tertentu (Kim et al., 2010). Metode ini adalah dikembangkan sebagai alternatif kartu kredit dan kartu debit untuk e-commerce. Uang tunai elektronik adalah informasi yang setara dengan uang kertas fisik dan koin (Zwass 1996). Individu harus membeli uang digital elektronik dari perusahaan penerbit agar dapat gunakan sistem ini (Abrazhevich 2004). Uang tunai digital yang dibeli dapat ditransfer melalui saluran telekomunikasi elektronik (Hsieh 2001; Kim et al., 2010).

Kartu prabayar: Kartu prabayar dihasilkan untuk nilai tertentu oleh pedagang tertentu dan digunakan untuk transaksi dalam toko atau online (Kim et al., 2010; Kniberg 2002). Meskipun, dalam praktiknya kartu prabayar diberikan sebagai 'kartu hadiah' di mana penerima hadiah dapat memilih barang atau jasa hingga jumlah yang dimuat sebelumnya pada kartu, itu juga umum di mana mereka digunakan oleh seorang individu yang melakukan pra-pengisian kartu untuk penggunaan pribadi. Atau, perusahaan menyediakan kartu pra-bayar sebagai bagian dari strategi manajemen hubungan pelanggan mereka dalam bentuk hadiah perusahaan atau kompensasi pelanggan individu yang mengalami ketidakpuasan. Orang yang ingin menggunakan kartu prabayar online, memasukkan nomor kartu unik pada situs web penjual untuk membayar barang atau jasa selama proses check-out. Jumlah untuk dibayarkan kepada penjual dikurangi dari nilai kartu. Sebagian besar kartu pra-bayar hanya digunakan satu kali dan habis setelah jangka waktu tertentu jika tidak digunakan; sejumlah bisnis mulai memungkinkan pelanggan untuk menggunakan kartu prabayar tanpa tanggal kedaluwarsa dan pada lebih dari satu transaksi dalam periode waktu tertentu (mis.: dalam waktu satu bulan dari penggunaan pertama). Alasan mengapa kartu pra-bayar lebih disukai oleh konsumen adalah kemudahan penggunaannya dan kenyamanan (Kim et al., 2010). 
Kartu kredit: Kartu kredit adalah kartu pembayaran plastik yang diberikan kepada pengguna untuk membuat online atau transaksi keuangan offline. Kartu kredit adalah bentuk pembayaran elektronik yang paling sering digunakan (Hsieh 2001; Kim et al., 2010). Visa, yang merupakan salah satu perusahaan kartu kredit terbesar, melaporkan bahwa pembelian elektronik mencapai \$350 miliar tahun ini. Kartu kredit sangat rumit struktur transaksi dan menyediakan media yang aman bagi penggunanya (Wright 2002). Dibandingkan ke SPE lain, kartu kredit tidak sesuai untuk pembayaran mikro (mis., pembayaran lebih kecil dari \$1) tidak seperti uang tunai elektronik.

Kartu debit: Kartu debit (juga dikenal sebagai kartu bank atau kartu cek) adalah kartu plastic yang memungkinkan individu untuk menarik uang tunai dari rekening bank mereka melalui teller otomatis mesin (ATM) tanpa interaksi tatap muka di bank, serta untuk membayar barang dan layanan online dan offline. Kartu debit dikeluarkan oleh bank (publik / swasta) dan penyedia layanan keuangan. Tidak seperti kartu kredit, sekali seseorang membayar dengan kartu debit, jumlah tersebut secara otomatis dikurangkan dari rekening banknya. Kartu debit adalah salah satunya metode pembayaran elektronik yang paling sering digunakan (Kim et al., 2010).

Berdasarkan ulasan di atas, jelas bahwa kartu pra-bayar, kredit dan debit adalah kartu metode pembayaran elektronik yang paling sering digunakan, sedangkan metode kas elektronik sudah beroperasi sebagai pelengkap bagi mereka. Uang tunai elektronik sebagian besar digunakan untuk nilai kecil transaksi sementara kartu prabayar, kredit dan debit telah digunakan untuk sebagian besar jenis transaksi kecuali transaksi bernilai kecil. Alasan untuk tidak menggunakan pra-bayar, kredit dan kartu debit untuk transaksi bernilai kecil adalah harganya bisa mahal secara tidak proporsional gunakan metode ini untuk jumlah kecil. Karena tidak ada satu pun metode pembayaran elektronik yang mendominasi sektor, semua metode dapat dilihat sebagai alternatif satu sama lain. Selanjutnya, keamanan, mekanisme keamanan, dan kemudahan penggunaan adalah elemen penting bagi individu saat memutuskan pada jenis SPE yang akan digunakan. Pentingnya harus diberikan secara tepat kepada elemen-elemen ini di untuk mengurangi risiko transaksi dan meningkatkan penggunaan SPE. Bagian selanjutnya akan mengulas literatur untuk mengidentifikasi faktor-faktor yang mempengaruhi persepsi keamanan dan konsumen persepsi kepercayaan dalam penggunaan SPE.

Kurangnya rasa aman dan kepercayaan yang dirasakan telah diidentifikasi sebagai salah satu faktor paling vital memperlambat perkembangan e-commerce (Centeno 2002). Untuk membangun kepercayaan dan keamanan dalam SPE, penting untuk memberikan perlindungan teknis kepada pengguna (Kim et al., 2010). Demikian pula, Kalakota dan Whinston (1997) 
menemukan bahwa keandalan teknis dan resistensi SPE terhadap serangan keamanan adalah dua faktor yang mempengaruhi keamanan SPE. Selanjutnya, infrastruktur teknis, implementasi, aturan transaksi yang jelas, dan faktor hukum (mis. kerangka hukum) telah ditemukan sebagai faktor penting untuk keamanan SPE dan kepercayaan. Akhirnya, Romdhane (2005) meninjau literatur yang ada dan menyatakan bahwa aman Sistem EP harus menunjukkan sembilan elemen. Elemen-elemen ini adalah otentikasi, pencegahan penipuan, kerahasiaan, pembagian, transferability, duplikasi pencegahan pengeluaran, privasi pembayaran, anonimitas pembayaran, dan keterlacakan pembayar.

Selain itu, prosedur transaksi juga telah diidentifikasi sebagai faktor yang mempengaruhi keamanan dan kepercayaan pada SPE (Hwang, Li, \& Hsiao 2006; Kim et al., 2010). Seperti yg disebutkan sebelumnya, SPE berbeda dari metode pembayaran tradisional dan sifatnya dihadapkan dengan berbagai masalah keamanan baru (Lim 2008). Beberapa masalah keamanan ini termasuk penggunaan SPE dan status transaksi tanpa izin (Kim et al., 2010; Linck et al., 2006). Menurut Laudon dan Traver (2001), Kim et al. (2010) dan Lawrence, Newton, Corbitt, Braithwaite, dan Parker (2002) prosedur dan proses transaksi yang canggih interaksi harus dikembangkan untuk meminimalkan dan / atau menghilangkan persepsi konsumen masalah keamanan dan kepercayaan. Pentingnya keamanan dan kepercayaan pada SPE telah disebutkan sebelumnya, maka peningkatan elemen-elemen ini akan mendorong penggunaan SPE.

Pernyataan keamanan juga ditemukan sebagai faktor penting yang memengaruhi konsumen persepsi keamanan dan kepercayaan (Mukherjee \& Nath 2003). Istilah 'pernyataan keamanan' adalah didefinisikan sebagai informasi yang dikirimkan kepada pengguna (konsumen) untuk proses dan keamanan SPE solusi. Menurut Miyazaki dan Fernandez (2000b), pernyataan keamanan diposting di situs web cenderung meningkatkan niat untuk membeli melalui internet. Temuan khusus ini juga didukung oleh konsep asimetri informasi. Rujukan asimetri informasi ke 'situasi di mana salah satu pihak yang terlibat dalam transaksi tidak memiliki akses semua informasi yang diperlukan untuk pengambilan keputusan '(Kim et al., 2010, hal. 86). Masalah asimetri informasi telah menjadi masalah berkelanjutan untuk SPE sejak kemunculannya (Mukherjee \& Nath 2003). Friedman, Howe, dan Felten (2002) dan Mukherjee dan Nath (2003) menyatakan konten deskriptif tentang masalah keamanan dan privasi (mis. pernyataan keamanan) harus memengaruhi persepsi konsumen terhadap kepercayaan dan keamanan dalam SPE. Apalagi deskriptif konten juga membantu konsumen untuk membangun interpretasi keamanan SPE yang lebih akurat (Friedman et al., 2002) 
Penelitian sebelumnya telah menemukan bahwa perlindungan informasi adalah elemen vital yang mempengaruhi penggunaan SPE (Kim et al., 2010; Linck et al., 2006). Mayoritas dari penelitian yang berfokus pada perincian teknis perlindungan seperti privasi dan integritas. Namun, menurut Kim et al. (2010) dan Mukherjee dan Nath (2003), metode yang digunakan untuk otentikasi, konfirmasi, dan modifikasi juga penting dalam penggunaan SPE dan harus diperiksa ketika penggunaan SPE adalah masalah perlindungan.

Akhirnya, pengalaman masa lalu diakui sebagai faktor lain yang mempengaruhi penggunaan SPE. Menurut Wu dan Wang (2005), pengalaman masa lalu akan meningkatkan peluang adopsi dan penggunaan teknologi dan sistem baru (mis. SPE). Selanjutnya, Patton dan Jøsang (2004) dan Pichler (2000) menyatakan bahwa kepercayaan didasarkan pada pengalaman dari waktu ke waktu dan semakin dalam sebagai fungsi dari pengalaman masa lalu. Miyazaki dan Fernandez (2001) menemukan itu pengalaman masa lalu berhubungan negatif dengan adanya kekhawatiran terkait keamanan dari perdagangan elektronik. Dengan demikian, diharapkan pengalaman masa lalu akan mempengaruhi persepsi pelanggan keamanan dan kepercayaan pada SPE. Berdasarkan tinjauan literatur, empat faktor yang mempengaruhi persepsi konsumen tentang keamanandan kepercayaan pada SPE telah diidentifikasi. Faktorfaktor ini adalah pernyataan keamanan; transaksi prosedur; perlindungan teknis dan pengalaman masa lalu pribadi dengan SPE.

Penelitian grup ini mengacu pada jurnal penelitian yang dilakukan oleh Emrah Oney, Gizem Oksuzoglu Guven \& Wajid Hussain Rizvi (2017), dengan judul : “The Determinants of Electronic Payment Systems Usage from Consumers' Perspective Economic", dimana dalam abstraksinya disebutkan bahwa SPE telah meningkatkan kualitas hidup individu melalui pemberian kemudahan pembayaran untuk online transaksi. Efek dari kepercayaan dan keamanan terhadap penggunaan SPE yang dimiliki sudah lama dikenal dalam literatur ecommerce. Namun, sangat sedikit studi telah memeriksa kedua konsep ini dari sudut pandang penggunanya. Penelitian ini telah mengembangkan model konseptual untuk menguji penentu persepsi keamanan dan kepercayaan serta dampaknya terhadap persepsi keamanan dan kepercayaan pada penggunaan SPE. Sampel dari 262 responden dianalisa melalui pemodelan persamaan structural; dan temuannya menunjukkan bahwa perasaan aman dan percaya pada SPE memiliki pengaruh signifikan terhadap penggunaan SPE. Perlindungan teknis dan pengalaman masa lalu telah ditemukan sebagai penentu umum keamanan dan kepercayaan yang dipersepsikan tersebut.

Beberapa penelitian telah mengeksplorasi hubungan antara persepsi keamanan, persepsi kepercayaan dan penggunaan Sistem Pembayaran Elektonik (SPE). Pengecualian penting 
adalah studi Kim et al. (2010) dan Theodosios dan George (2005). Mereka menyimpulkan bahwa persepsi keamanan dan kepercayaan yang dirasakan memiliki signifikansi, efek positif pada penggunaan (SPE). Sejalan dengan itu, Theodosios dan George (2005) mengklaim bahwa penyedia SPE harus mempertimbangkan kepercayaan dan keamanan akun sebagai penentu penting penggunaan konsumen SPE. Studi ini meminjam model penelitian Kim et al. (2010), yang dirancang untuk menguji pengaruh persepsi keamanan dan kepercayaan terhadap penggunaan SPE konsumen. Seperti disebutkan sebelumnya, keduanya persepsi keamanan dan kepercayaan adalah masalah penting untuk penggunaan SPE.

Kurangnya keamanan yang dirasakan dan kepercayaan dapat mengikis kesediaan konsumen untuk menggunakan SPE (Linck et al., 2006; Mukherjee \& Nath 2003). Oleh karena itu, penting untuk mempelajari faktor-faktor yang mempengaruhi persepsi keamanan dan kepercayaan. Gambar 1 merangkum model penelitian, berdasarkan hipotesis penelitian yang dikembangkan. Meskipun, beberapa faktor yang diidentifikasi dalam model ini telah digunakan dalam penelitian sebelumnya (mis. Kim et al., 2010), model penelitian kami mengidentifikasi penentu baru yang dianggap penting untuk persepsi keamanan dan kepercayaan konsumen. Seperti yang ditunjukkan dalam model, perlindungan teknis, prosedur transaksi, pernyataan keamanan dan pengalaman masa lalu dengan SPE adalah faktor utama untuk persepsi konsumen tentang keamanan dan kepercayaan dalam penggunaan SPE. Faktorfaktor ini diyakini memiliki pengaruh signifikan terhadap keamanan yang dirasakan konsumen dan percaya pada SPE.

Gambar 1. Model konseptual keamanan dan kepercayaan yang dirasakan dalam penggunaan SPE.

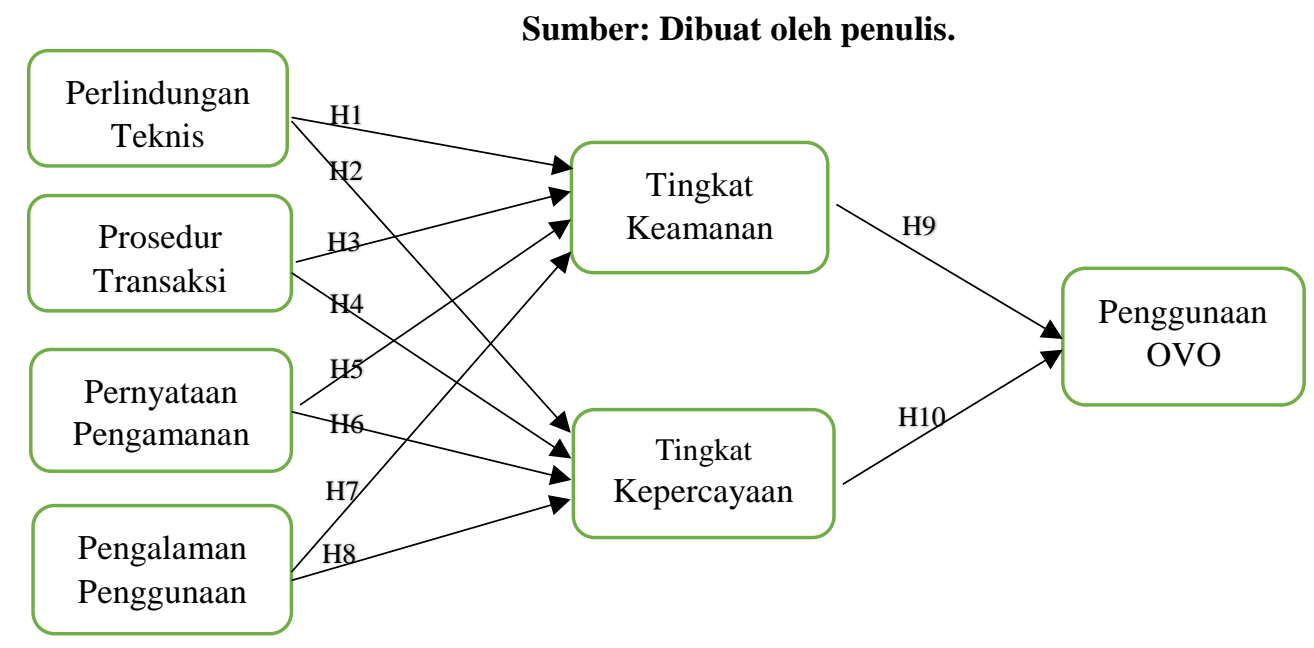

\section{Perlindungan teknis pada OVO}

Perlindungan teknis telah diterima sebagai anteseden penting untuk keamanan SPE (Kim et al., 2010). Banyak perlindungan teknis telah dikembangkan dan dimanfaatkan secara 
berurutan untuk memastikan keamanan pembayaran elektronik (Linck et al., 2006). Demikian juga, Kim et al. (2010) dan Chellappa dan Pavlou (2002) menyebutkan bahwa perlindungan teknis (termasuk privasi, integritas dan stabilitas) memiliki efek positif pada persepsi keamanan dan kepercayaan. Dengan kata lain, memberikan perlindungan teknis yang memadai akan meningkatkan persepsi keamanan dan keamanan konsumen percaya pada SPE. Berdasarkan temuan ini, diusulkan bahwa:

Hipotesis 1. Perlindungan teknis memiliki efek signifikan dan positif pada tingkat keamanan yang dirasakan dalam OVO.

Hipotesis 2. Perlindungan teknis memiliki efek signifikan dan positif pada tingkat kepercayaan pada OVO.

\section{Prosedur transaksi pada OVO}

Prosedur transaksi sangat penting bagi individu untuk dapat menggunakan SPE dengan aman dan efisien. Menurut Hwang, Shiau, dan Jan (2007) dan Kim et al. (2010), transaksi yang jelas prosedur membantu individu untuk menghilangkan masalah keamanan mereka. Secara umum, tiga utama prosedur transaksi digunakan selama transaksi moneter elektronik. Ini prosedurnya adalah: (1) mengautentikasi setiap pengguna sebelum bertransaksi; (2) pengguna diberikan beberapa prosedur menuju penyelesaian pembayaran; (3) mengirim konfirmasi untuk setiap pengguna setelah selesai pembayaran (Hwang et al., 2007). Diyakini bahwa prosedur transaksi akan berdampak pada persepsi keamanan dan kepercayaan.

Hipotesis 3. Prosedur transaksi berpengaruh signifikan dan positif terhadap tingkat keamanan yang dirasakan dalam OVO.

Hipotesis 4. Prosedur transaksi berpengaruh signifikan dan positif terhadap tingkat kepercayaan pada OVO

\section{Pernyataan keamanan pada OVO}

Telah ditemukan sebagai faktor penting yang memengaruhi Tingkat Kepercayaan dalam SPE (Kim et al., 2010; Mukherjee \& Nath 2003). Menurut Kim et al. (2010), keputusan konsumen untuk menggunakan SPE akan sangat bergantung pada pernyataan keamanan diposting karena pernyataan ini dapat meningkatkan persepsi keamanan dan kepercayaan konsumen SPE. Demikian pula, Miyazaki dan Fernandez (2000a) menyatakan bahwa pernyataan keamanan diposting pada SPE akan meningkatkan kemungkinan pembelian konsumen melalui Internet. Berdasarkan hal tersebut, dihipotesiskan bahwa:

Hipotesis 5. Pernyataan keamanan memiliki pengaruh signifikan dan positif terhadap tingkat keamanan yang dirasakan dalam OVO. 


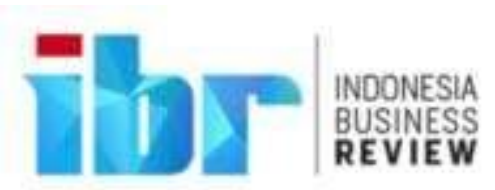

Vol. 3. No. 2, 2020

Hipotesis 6. Pernyataan keamanan memiliki efek signifikan dan positif pada tingkat kepercayaan pada OVO.

\section{Pengalaman masa lalu pribadi}

Pengalaman masa lalu akan mengarah pada adopsi dan konsumsi teknologi baru yang lebih cepat (mis. SPE) (Wu \& Wang 2005). Demikian pula, Hackbarth, Grover, dan Yi (2003) menyebutkan bahwa individu lebih nyaman menggunakan inovasi teknologi baru ketika mereka memilikinya pengalaman sebelumnya. Alasan untuk ini terjadi adalah bahwa pengalaman masa lalu membangun kepercayaan (Eastin 2002) dan berhubungan negatif dengan adanya kekhawatiran terkait keamanan EC (Miyazaki \& Fernandez 2001). Dengan demikian, konsumen dengan pengalaman masa lalu SPE akan mempercayai ini sistem dan melihatnya sebagai cara aman untuk menyelesaikan transaksi. Karena itu, dihipotesiskan bahwa;

Hipotesis 7. Pengalaman pengguna OVO memiliki efek signifikan dan positif pada tingkat keamanan yang dirasakan dalam OVO.

Hipotesis 8. Pengalaman pengguna OVO memiliki efek signifikan dan positif pada tingkat kepercayaan pada OVO.

\section{Persepsi keamanan pada OVO}

Kim et al. (2010) telah mendefinisikan persepsi keamanan sebagai evaluasi subyektif Tingkat Keamanan SPE. Konsumen dapat menganalisis dan menilai keamanan SPE berbeda. Dengan demikian, keamanan yang dirasakan dari SPE dapat bervariasi antar individu. Tingkat persepsi keamanan memiliki dampak besar pada keputusan konsumen mengenai penggunaan SPE. Jika tingkat keamanan yang dirasakan dalam SPE terlalu rendah, konsumen tidak mungkin terlibat dalam transaksi (Kim et al., 2010; Tsiakis \& Sthephanides 2005). Keamanan adalah salah satu yang penting pemicu penggunaan SPE. Dengan demikian, dihipotesiskan bahwa: Hipotesis 9. Tingkat Keamanan yang dirasakan dalam OVO memiliki efek yang signifikan dan positif pada konsumen Penggunaan OVO

\section{Persepsi kepercayaan pada OVO}

Earle (2009, p. 786) menggambarkan kepercayaan sebagai 'kesediaan, dengan harapan hasil yang bermanfaat, untuk membuat diri rentan terhadap orang lain berdasarkan penilaian kesamaan niat atau nilai'. Sejalan dengan itu, Tsiakis dan Sthephanides (2005) telah mendefinisikan persepsi kepercayaan sebagai keyakinan konsumen bahwa transaksi pembayaran elektronik akan diproses sesuai dengan harapan mereka. Kepercayaan telah diidentifikasi sebagai salah satu faktor terpenting yang memengaruhi penggunaan SPE oleh konsumen dan konsumen dengan tingkat kepercayaan yang lebih tinggi telah ditemukan lebih 
rentan menggunakan SPE (Kim et al., 2010; Tsiakis \& Sthephanides 2005). Begitu pula Kim et al. (2010) menyebutkan bahwa SPE mustahil untuk mendapatkan penggunaan luas tanpa kepercayaan. Lebih jauh, telah ditemukan bahwa kepercayaan lebih penting daripada keamanan dan tanpa kepercayaan konsumen tidak akan menggunakan SPE untuk menyelesaikan transaksi mereka (Zallat 2007). Dengan demikian, telah dihipotesiskan bahwa: Hipotesis 10. Tingkat kepercayaan dalam OVO memiliki efek signifikan dan positif pada konsumen penggunaan OVO

\section{Metodologi Penelitian}

Penelitian ini dilakukan di propinsi DKI Jakarta, karena DKI Jakarta menjadi pusat aktifitas ekonomi masyarakat Indonesia. Tingkat pertumbuhan ekonomi yang baik akan berdampak baik pada kegiatan ekonomi, dengan demikian penggunaan OVO akan meningkat. Penelitian ini bertujuan untuk melakukan analisa terhadap beberapa variabel yang dapat berpengaruh pada penggunaan OVO oleh masyarakat, khususnya di propinsi DKI Jakarta. Waktu penelitian ini dilakukan pada pertengahan bulan Juni 2019 sampai dengan awal bulan Agustus 2019.

Jenis data yang digunakan merupakan data primer Data primer yang diperoleh dengan metode survei kepada masyarakat umum melalui panduan berupa kuesioner, dan kemudian kuesioner disebarkan melalui sistem online. Objek dari kuesioner ini adalah 262 orang masyarakat umum dengan usia responden yang tidak dibatasi. Skala pengukuran kuesioner ini berupa nilai 1 sampai dengan 7, dimana penilaian 1 mempunyai arti sangat tidak setuju sampai dengan penilaian 7 yang berarti sangat setuju, dan nilai 4 untuk netral.

Metode yang digunakan dalam penelitian ini adalah survei dengan melakukan riset pada masyarakat untuk mendapatkan data primer. Survei pada masyarakat dilakukan dengan melakukan wawancara pada masyarakat dengan panduan berupa kuesioner, dimana penelitian ini dilakukan di propinsi DKI Jakarta. Jenis Variabel yang diamati (Variabel Eksogen) dalam penelitian ini adalah jenis kelamin, usia, status, pendidikan terakhir, pekerjaan dan pendapatan rata-rata per bulan, sehingga persepsi responden terhadap nilai motivasi dalam menggunakan OVO dapat terukur.

\section{Analisis Data}

Dari kuesioner yang kami sebarkan terkumpul data dari sampel 262 masyarakat DKI Jakarta. Pra-pengujian yang ketat memastikan pemahaman semua pertanyaan. Masyarakat DKI Jakarta adalah kelompok perwakilan dari pembeli online tipikal dalam elektronik dunia 
perdagangan, terutama karena keakraban mereka dengan komputer dan e-commerce. Kuesioner terstruktur, berbasis online ini memiliki tujuh bagian: perlindungan teknis, prosedur transaksi, pernyataan pengamanan, pengalaman pengguna, tingkat keamanan, tingkat kepercayaan, dan penggunaan sistem pembayaran OVO. Pengumpulan data dimulai dari 31 Juli 2019 sampai dengan tanggal 12 Agustus 2019. Sampel akhir menyatakan bahwa 83,9\% responden adalah karyawan dan 7,7\% responden adalah wiraswasta, dan sisanya adalah pelajar, ibu rumah tangga dan pensiunan.

Perlindungan teknis (5 item), prosedur transaksi (6 item), pernyataan pengamanan (6 item), pengalaman pengguna (5 item), tingkat keamanan (4 item) dan tingkat kepercayaan (4 item), pengguna transaksi pembayaran online OVO (3 item) diukur dengan skala yang dipinjam dari Kim et al. (2010). Pengalaman pribadi dengan EPS tadinya diukur dengan skala lima item, yang dikembangkan oleh penulis untuk tujuan belajar. Kategori tanggapan tipeLikert tujuh poin (mis., 1 = sangat tidak setuju; 7 = sangat setuju) digunakan untuk semua skala yang digunakan. Penelitian ini mengukur perlindungan teknis melalui privasi; integritas; dan kerahasiaan; prosedur transaksi melalui otentikasi;modifikasi; dan konfirmasi dan pernyataan keamanan melalui ketersediaan; aksesibilitas; dan kelengkapan (Kim et al., 2010). Statistik deskriptif skor rata-rata yang dirangkum rata-rata dan standar deviasi yang sesuai untuk semua konstruksi dalam penelitian ini disajikan pada Tabel 1.

Tabel 1. Descriptive Statistics dari Konstruksi yang diteliti $(\mathbf{N}=262)$

\begin{tabular}{|l|r|r|r|r|r|}
\hline \multicolumn{7}{|c|}{ Descriptive Statistics } \\
\hline & N & Minimum & Maximum & Mean & $\begin{array}{c}\text { Std. } \\
\text { Deviation }\end{array}$ \\
\hline Perlindungan_Teknis & 262 & 2,80 & 7,00 & 6,1527 & 0,81681 \\
\hline Prosedur_Transaksi & 262 & 2,83 & 7,00 & 5,5776 & 0,89099 \\
\hline Pernyataan_Keamanan & 262 & 1,50 & 7,00 & 5,5394 & 1,01601 \\
\hline Tingkat_Kepercayaan & 262 & 2,25 & 7,00 & 5,4485 & 1,11427 \\
\hline Tingkat_Keamanan & 262 & 1,00 & 7,00 & 5,4141 & 1,18753 \\
\hline Pengalaman_dalam_Pengguna & 262 & 1,00 & 7,00 & 5,8397 & 1,06607 \\
\hline Penggunaan_Sistem_Pembayaran_Elektronik & 262 & 1,00 & 7,00 & 5,5013 & 1,25428 \\
\hline Valid N (listwise) & 262 & & & & \\
\hline
\end{tabular}

Statistik deskriptif skor rata-rata yang dirangkum rata-rata dan standar deviasi yang sesuai untuk semua konstruksi dalam penelitian ini disajikan pada Tabel 1. Sepanjang pengukuran 7 poin skala, rata-rata yang dilaporkan skor penggunaan sistem pembayaran online OVO. Pada tabel berikut menjelaskan bahwa jumlah dari sampel penelitian ini sudah memenuhi dan dapat dilanjutkan penelitiannya.

\begin{tabular}{|l|l|r|}
\hline \multicolumn{3}{|c|}{ KMO and Bartlett's Test } \\
\hline Kaiser-Meyer-Olkin Measure of Sampling Adequacy. & 0,943 \\
\hline Bartlett's Test of Sphericity & Approx. Chi-Square & 6719,774 \\
\cline { 2 - 3 } & df & 528 \\
\cline { 2 - 3 } & Sig. & 0,000 \\
\hline
\end{tabular}




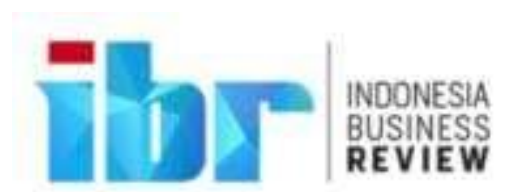

Vol. 3. No. 2, 2020

Dinyatakan juga bahwa semua konstruk yang telah disusun berdasarkan dari perhitungan analisa yang ada dinyatakan sudah sesuai dengan variable kuesioner'

\begin{tabular}{|c|c|c|c|c|c|c|c|}
\hline & & Rot: & d Comp & ent $\mathrm{Ma}$ & & & \\
\hline & & & & mponent & & & \\
\hline & 1 & 2 & 3 & 4 & 5 & 6 & 7 \\
\hline$\sqrt{\sqrt{3}}$ & & & & 0,607 & & & \\
\hline$\overline{V 4}$ & & & & 0,769 & & & \\
\hline V5 & & & & 0,733 & & & \\
\hline$\sqrt{66}$ & & & & 0,732 & & & \\
\hline$\sqrt{7}$ & & & & 0,598 & & & \\
\hline$\overline{V 8}$ & & & & & & & 0,624 \\
\hline$\overline{V 9}$ & & & & & & & 0,495 \\
\hline $\mathrm{V} 10$ & & & & & & & 0,425 \\
\hline$\overline{V 11}$ & & & & & & & 0,634 \\
\hline$\overline{V 12}$ & & & & & & & 0,489 \\
\hline \begin{tabular}{|l|}
$V 13$ \\
\end{tabular} & & & & & & & 0,905 \\
\hline$\overline{V 14}$ & & 0,691 & & & & & \\
\hline V15 & & 0,741 & & & & & \\
\hline V16 & & 0,751 & & & & & \\
\hline \begin{tabular}{|l|}
$\mathrm{V} 17$ \\
\end{tabular} & & 0,722 & & & & & \\
\hline \begin{tabular}{|l|} 
V18 \\
\end{tabular} & & 0,794 & & & & & \\
\hline$\sqrt{\mathrm{V} 19}$ & & 0,719 & & & & & \\
\hline$\sqrt{20}$ & 0,751 & & & & & & \\
\hline V21 & 0,766 & & & & & & \\
\hline$\sqrt{122}$ & 0,595 & & & & & & \\
\hline$\overline{V 23}$ & 0,774 & & & & & & \\
\hline$\sqrt{224}$ & & & & & & 0,746 & \\
\hline$\sqrt{25}$ & & & & & & 0,827 & \\
\hline V26 & & & & & & 0,761 & \\
\hline \begin{tabular}{|l}
$\sqrt{27}$ \\
\end{tabular} & & & & & & 0,846 & \\
\hline$\overline{V 28}$ & & & 0,740 & & & & \\
\hline$\overline{V 29}$ & & & 0,783 & & & & \\
\hline V30 & & & 0,775 & & & & \\
\hline$\sqrt{31}$ & & & 0,727 & & & & \\
\hline$\sqrt{32}$ & & & \begin{tabular}{|c|}
0,678 \\
\end{tabular} & & & & \\
\hline$\sqrt{\sqrt{33}}$ & & & & & 0,827 & & \\
\hline$\sqrt{\mathrm{V34}}$ & & & & & 0,795 & & \\
\hline$\sqrt{135}$ & & & & & 0,686 & & \\
\hline
\end{tabular}

\section{Kesimpulan}

Dalam penelitian ini, upaya telah dilakukan untuk melakukan identifikasi faktor-faktor penentu keamanan yang dirasakan dan persepsi kepercayaan serta pengaruhnya terhadap penggunaan OVO. Konsep keamanan dan kepercayaan telah diperiksa dari sudut pandang pengguna OVO untuk memberikan pemahaman yang lebih dalam konstruksi ini karena menyoroti wawasan pengguna OVO. Temuan kami menunjukkan bahwa persepsi keamanan dan persepsi kepercayaan memiliki efek positif dan berpengaruh terhadap penggunaan OVO. Oleh karena itu, ketika pengguna menganggap OVO sebagai alat pembayaran yang aman dan dapat dipercaya, mereka menjadi lebih bersedia untuk menyelesaikan transaksi mereka secara elektronik. Hasilnya konsisten dengan literatur yang ada (Culnan \& Armstrong 1999; Kim et al., 2010) dan juga menunjukkan bahwa perlindungan teknis adalah penentu terkuat baik untuk keamanan yang dirasakan maupun kepercayaan. Temuan ini konsisten dengan 


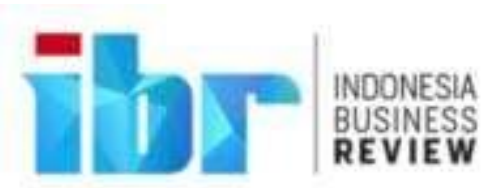

Vol. 3. No. 2, 2020

penelitian sebelumnya. Demikian juga bukti yang menunjukkan bahwa dengan memberikan perlindungan teknis kepada pengguna OVO diyakini dapat meningkatkan perasaan aman dan percaya dari sisi konsumen.

Lebih lanjut, tidak ada pengaruh yang berpengaruh dari prosedur transaksi terhadap persepsi keamanan dan kepercayaan yang telah ditemukan. Efek (tidak berpengaruh) yang ditemukan dalam penelitian ini juga konsisten dengan temuan dalam Kim et al. (2010) menyatakan bahwa prosedur transaksi bukan merupakan penentu persepsi keamanan dan kepercayaan. Namun, temuan dalam penelitian ini dan temuan oleh Kim et al. (2010) berbeda dari yang dilaporkan oleh Romdhane (2005). Dalam Romdhane's (2005) pengaruh yang signifikan terhadap prosedur transaksi, persepsi keamanan dan kepercayaan telah diidentifikasi. Berdasarkan temuan ini, dapat dinyatakan bahwa tidak mungkin prosedur transaksi adalah merupakan parameter untuk keamanan dan kepercayaan terhadap OVO, sehingga pada umumnya bisa diterima sebagai praktik yang digunakan. Oleh karena itu, prosedur transaksi dapat menyebabkan ketidaknyamanan untuk pengguna dari waktu ke waktu dan menurunkan penilaian keamanan dan kepercayaan pengguna terhadap OVO. Akhirnya, pengalaman masa lalu pribadi dalam penggunaan OVO telah ditemukan sebagai keadaan umum persepsi keamanan dan kepercayaan. Temuan ini sejalan dengan penelitian Pavlou and Gefen (2004). Menurut hasil ini, individu membangun rasa aman dan kepercayaan mereka berdasarkan pada pengalaman masa lalu mereka.

\section{Implikasi manajerial}

Penelitian ini menunjukkan bahwa persepsi keamanan dan persepsi kepercayaan dapat meningkatkan penggunaan OVO. Fokus manajerial harus bertumpu pada pemberian perlindungan dan penyediaan teknis semaksimal mungkin terhadap sistem yang aman bagi pengguna. Hasil penelitian ini menunjukkan bahwa pengguna membutuhkan sistem yang ramah dalam penggunaan, mudah digunakan dan sistem yang bebas dari masalah untuk merasa aman dan percaya pada layanan OVO. Selain itu, pengalaman masa lalu merupakan salah satu penentu yang penting dan berhubungan dengan rasa keamanan dan kepercayaan. Pengalaman masa lalu yang positif akan sangat berpengaruh terhadap kepercayaan dan perasaan aman konsumen terhadap OVO. Akhirnya, dan yang paling penting, rasa keamanan dan kepercayaan yang dirasakan telah ditemukan sebagai penentu yang penting dari penggunaan OVO.

Studi ini tidak menemukan bukti bahwa ada hubungan yang signifikan secara statistik antara prosedur transaksi dan persepsi kepercayaan dan keamanan konsumen dalam 
penggunaan OVO. Penelitian ini menguji efek terpisah dari persepsi keamanan dan persepsi kepercayaan tentang penggunaan OVO. Studi selanjutnya dapat menguji efek gabungan dari variabel-variabel ini pada penggunaan OVO melalui analisis regresi polinomial. Metode ini akan menunjukkan bagaimana kombinasi dari dua variabel prediktor ini (persepsi keamanan dan persepsi kepercayaan) terkait dengan penggunaan OVO.

\section{Daftar Pustaka}

- Statistik Transaksi Uang Elektronik, Bank Indonesia, Jakarta 2019

- Techniasia Website, Karisma G. 2019, Riset Snapcart Menambah Panjang Peta Persaingan Fintech Indonesia, https://id.techinasia.com/snapcart-dompet-digitalindonesia2019, (2 Agustus 2019)

- CNBC Indonesia, Franedya R. 2019, Ada Fintech, Morgan Stanley: Pembayaran Digital RI Rp $700 \quad \mathrm{~T}, \quad$ https://www.cnbcindonesia.com/tech/20190221104612-37-56808/adafintechmorgan-stanley-pembayaran-digital-ri-rp-700-t, (2 Agustus 2019)

- Tirto, Purnamasari D., 2017, 50,90\% Masyarakat Khawatirkan Penggunaan Data eMoney, https://tirto.id/cy41. (2 Agustus 2019)

- Ravi Kalakota, 1997, Electronic Commerce: A Manager's GuidelLinck, Pousttchi, dan Wiedemann, 2006, Security issues in mobile payment from the customer viewpoint

- Shon \& Swatman, 1998, Identifying effectiveness criteria for Internet payment systems

- Moorman, Deshpande, \& Zaltman, 1993, Factors Affecting Trust in Market Research Relationships

- Tsiakis \& Sthephanides 2005, The Concept of Security and Trust in Electronic Payments

- Dahlberg, Dahlberg, \& Nyström 2008, Reflective Lifeworld Research

- Eastlick, Lotz, dan Warrington 2006, Eastlick, Understanding online B-to-C relationships

- Gartner Group 2001, What is Big Data?

- Abrazhevich, D. (2004). Electronic payment systems: A user-centred perspective and interaction design. Netherlands: Universiteitsdrukkerij Technische Universiteit Eindhoven.

- Anderson, J. C., \& Gerbing, D. W. (1988). Structural equation modelling in practice: A review and recommended two steps. Psychological Bulletin, 103, 411-423.

- Bagozzi, R. P., \& Yi, Y. (1988). On the evaluation of structural equation models. Journal of Academy of Marketing Science, 16, 74-94. 
- Browne, M. W., \& Cudeck, R. (1993). Alternative ways of assessing model fit. In K. A. Bollen \& J. S. Long (Eds.), Testing structural equation models (pp. 136-162). Beverly Hills, Ca: Sage.

- Byne, B. M. (1994). Structural equation modelling with EQS and EQS/Windows: Basic concepts, applications, and programming. Thousand Oaks, CA: Sage.

- Centeno, C. (2002). Building security and consumer trust in internet payments: The potential of "soft" measures- Report EUR20278 EN. Spain: Institute for Prospective Technological Studies.

- Chellappa, R. K., \& Pavlou, P. A. (2002). Perceived information security, financial liability and consumer trust in electronic commerce transactions. Logistics Information Management, 15, 358-368.

- Culnan, M. J., \& Armstrong, P. K. (1999). Information privacy concerns, procedural fairness, and impersonal trust: An empirical investigation. Organization Science, 10, 104115.

- Dahlberg, K., Dahlberg, H., \& Nystrom, M. (2008). Reflective lifeworld research (2nd ed.). Sweden: Student litteratur.

- Earle, T. C. (2009). Trust, confidence, and the 2008 global financial crisis. Risk Analysis, 29, 785-792.

- Eastin, M. S. (2002). Diffusion of e-commerce: An analysis of the adoption of four ecommerce activities. Telematics and Informatics, 19, 251-267.

- Eastlick, M. A., Lotz, S. L., \& Warrington, P. (2006). Understanding online B-to-C relationships: An integrated model of privacy concerns, trust, and commitment. Journal of Business Research, 59, 877-886.

- Fornell, C., \& Larcker, D. F. (1981). Evaluating structural equation models with unobservable variables and measurement error. Journal of Marketing Research, 18, 39-50.

- Friedman, B., Howe, D. C., \& Felten, E. (2002). Informed consent in the Mozilla browser: Implementing value-sensitive design. 35th Annual Hawaii International Conference on System Sciences, HICSS'02, Washington DC, IEEE.

- Gartner Group. (2001). On-line fraud prevention white paper for the E-Commerce fraud prevention network. Retrieved August 26, 2013, from http://www.gartner.com

- Hackbarth, G., Grover, V., \& Yi ,M. Y. (2003). Computer playfulness and anxiety: Positive and negative mediators of the system experience effect on perceived ease of use. Information and Management, 40, 221-232. 
- Hair, J. F., Anderson, R. E., Babin, B. J., \& Black, W. C. (2010). Multivariate data analysis: A global perspective (7th ed.). Upper Saddle River, NJ: Pearson.

- Hair, J. F., Anderson, R. E., Tatham, R. L., \& Black, W. C. (1995). Multivariate data analysis with readings. Englewood Cliffs, NJ: Prentice-Hall.

- Hair, J., Anderson, R., Tatham, R., \& Black, W. (1998). Multivariate data analysis. NY: Macmillan.

- Hair, J. E., Anderson, R. L., Tatham, W. C., \& Black, W. C. (2007). Multivariate data analysis. Upper Saddle River, NJ: Prentice-Hall.

Hayduk, L. A. (1987). Structural equation modeling with LISREL: Essentials and advances. Baltimore, MD: Johns Hopkins University Press.

- Hsieh, C. T. (2001). E-commerce payment systems: Critical issues and management strategies. Human Systems Management, 20, 131-138.

- Hwang, R. J., Li, J. F., \& Hsiao, Y. K. (2006). A wireless-based authentication and anonymous channels for GSM system. Journal of Computers, 17, 31-36.

- Hwang, R. J., Shiau, S. H., \& Jan, D. F. (2007). A new mobile payment scheme for roaming services. Electronic Commerce Research and Applications, 6, 184-191.

- Joreskog, K. G., \& Sorborn, D. (1996). LISREL 8: User's reerence guide. Chicago, IL: Scientific Software.

- Kalakota, R., \& Whinston, A. B. (1997). Electronic commerce-A manager's guide. Reading, MA: Addision-Wesley.

- Kim, C., Tao, W., Shin, N., \& Kim, K. S. (2010). An empirical study of customers' perceptions of security and trust in e-payment systems. Electronic Commerce Research and Applications, 9, 84-95.

- Kniberg, H. (2002). What makes a micropayment solution succeed (Master's thesis). Institution for Applied Information Technology, Kungliga Tekniska Hogskolan, Kista.

- Laudon, K., \& Traver, C. (2001). E-commerce: Business, technology, society. Boston, MA: Addison- Wesley.

- Lawrence, E., Newton, S., Corbitt, B., Braithwaite, R., \& Parker, C. (2002) Technology of internet business. Milton, QLD: Wiley.

- Lee, Z. Y., Yu, H. C., \& Ku, P. J. (2001). An analysis and comparison of different types of electronic payment systems. Management of Engineering and Technology, 2001.

PICMET'01. Portland International Conference on, IEEE, 38-45, Portland. 
- Liao, C., Liu, C. C., \& Chen, K. (2011). Examining the impact of privacy, trust and risk perceptions beyond monetary transactions: An integrated model. Electronic Commerce Research and Applications, 10, 702-715.

- Lightner, N., Yenisey, M. M., Ozok, A. A., \& Salvendy, G. (2002). Shopping behavior and preferences in e-commerce of Turkish and American university students: Implications from cross-cultural design. Behavior and Information Technology, 21, 373-385

- Lim, A. S. (2008). Inter-consortia battles in mobile payments standardization. Electronic Commerce Research and Application, 7, 202-213.

Lim, B., Lee, H., \& Kurnia, S. (2007). Exploring the reasons for a failure of electronic payment systems: A case study of an Australian company. Journal of Research and Practice in Information Technology, 39, 231-244.

- Linck, K., Pousttchi, K., \& Wiedemann, D. G. (2006). Security issues in mobile payment from the customer viewpoint. Proceedings of the 14th European Conference on Information Zystems, (ECIS 2006), Goteborg, Schweden, 1-11.

- Zallat, N. (2007). Exploring consumer adoption of mobile payments - A qualitative study. Journal of Strategic Information Systems, 16, 413-432.

- Miyazaki, A. D., \& Fernandez, A. (2000a). Internet privacy and security: An examination of online retailer disclosures. Journal of Public Policy \& Marketing, 19, 54-61.

- Miyazaki, J., \& Fernandez, K. (2000b). The antecedents and consequences of trust in online purchase decisions. Journal of Interactive marketing, 16, 47-63.

- Miyazaki, J., \& Fernandez, K. (2001). Consumer perceptions of privacy and security risks for online shopping. The Journal of Consumer Affairs, 35, 27-44.

- Molla, A., Taylor, R., \& Licker, P. S. (2006). E-commerce diffusion in small Island countries: The influence of institutions in Barbados. The Electronic Journal of Information Systems in Developing Countries, 28, 1-15.

- Moorman, C., Deshpande, R., \& Zaltman, G. (1993). Factors affecting trust in market research relationships. The Journal of Marketing, 1, 81-101.

- Mukherjee, A., \& Nath, P. (2003). A model of trust in online relationship banking. International Journal of Bank Marketing, 21, 5-15.

- Patton, M. A., \& Josang, A. (2004). Technologies for trust in electronic commerce. Electronic Commerce Research, 4, 9-21.

- Pavlou, P. A., \& Gefen, D. (2004). Building effective online marketplaces with institutionbased trust. Information Systems Research, 15, 37-59. 
- Pichler, R. (2000). Trust and reliance-enforcement and compliance: Enhancing consumer confidence in the electronic marketplace (Doctoral dissertation). Stanford University, California.

- Reichheld, F. F., \& Schefter, P. (2000). E-loyalty. Harvard Business Review, 78, 105-113.

- Romdhane, C. (2005). Security implications of electronic commerce: A survey of consumers and businesses. Internet Research: Electronic Network Applications and Policy, 9, 372-382.

- Shon, T. H., \& Swatman, P. M. (1998). Identifying effectiveness criteria for Internet payment systems. Internet Research, 8, 202-218.

Theodosios, T., \& George, S. (2005). Concept of security and trust in electronic payment. Computers and Security, 24, 10-15.

- Thrassou, A., Vrontis, D., \& Kokkinaki, A. (2010). Internet consumer behavior in Cyprus. In S. Singh (Ed.), Handbook of business practices and growth in emerging markets (pp. 433-453). Singapore: World Scientific, Pte.

- Tsiakis, T., \& Sthephanides, G. (2005). The concept of security and trust in electronic payments. Computers \& Security, 24, 10-15.

- Van Dyke, T. P., Midha, V., \& Nemati, H. (2007). The effect of consumer privacy empowerment on trust and privacy concerns in e-commerce. Electronic Markets, 17, 6881. - Wright, D. (2002). Comparative evaluation of electronic payment systems. INFOR, $40,71-$

85.

- Wu, J. H., \& Wang, S. C. (2005). What drive mobile commerce? An empirical evaluation of the revised technology acceptance model. Information \& Management, 42, 719-729.

- Yahid, B., Shahbahrami, A., \& Nobakht, M. B. (2013, April). Providing security for ewallet using e-cheque. In e-Commerce in Developing Countries: With Focus on e-Security (ECDC), $20137^{\text {th }}$ Intenational Conference on (pp. 1-14). IEEE.

- Zwass, V. (1996). Electronic commerce: Structures and issues. International journal of electronic commerce, 1, 3-24. 


\section{Lampiran}

\section{KUESIONER}

Kajian ini dilakukan untuk menilai tingkat hubungan antara persepsi keamanan dan rasa percaya masyarakat terhadap Sistem Pembayaran Elektronik dengan kegunaan sistem pembayaran elektronik.

Ada tujuh alternative jawaban yang dapat dipilih, yaitu:
1 - Sangat tidak setuju
4 - Tidak keduanya
6 - Setuju
2 - Tidak setuju
5 - Agak setuju
7 - Sangat setuju
3 - Kurang setuju

\section{Berilah tanda silang ( $X$ ) pada jawaban yang paling sesuai dengan pilihan Anda.}

\begin{tabular}{|c|c|c|c|c|c|c|c|}
\hline Q1 - Technical Protections & $\begin{array}{c}\text { Sangat } \\
\text { tidak } \\
\text { setuju }\end{array}$ & $\begin{array}{l}\text { Tidak } \\
\text { setuju }\end{array}$ & $\begin{array}{l}\text { Kuran } \\
\text { g } \\
\text { setuju }\end{array}$ & $\begin{array}{l}\text { Tidak } \\
\text { keduan } \\
\text { ya }\end{array}$ & $\begin{array}{l}\text { Agak } \\
\text { setuju }\end{array}$ & Setuju & $\begin{array}{l}\begin{array}{l}\text { Sangat } \\
\text { setuju }\end{array} \\
\end{array}$ \\
\hline $\begin{array}{l}\text { a) Sistem Pembayaran OVO selalu membutuhkan password } \\
\text { pada saat Anda akses. }\end{array}$ & 1 & 2 & 3 & 4 & 5 & 6 & 7 \\
\hline $\begin{array}{l}\text { b) OVO menawarkan pilihan cara pembayaran sebelum } \\
\text { masuk ke tahapan terakhir dalam proses pembayaran. }\end{array}$ & 1 & 2 & 3 & 4 & 5 & 6 & 7 \\
\hline $\begin{array}{l}\text { c) OVO menyediakan langkah verifikasi pembayaran } \\
\text { sebelum finalisasi pembayaran yang aktual. }\end{array}$ & 1 & 2 & 3 & 4 & 5 & 6 & 7 \\
\hline $\begin{array}{l}\text { d) OVO secara khusus dapat menampilkan ringkasan } \\
\text { transaksi pembayaran dan jumlah total pembayaran. }\end{array}$ & 1 & 2 & 3 & 4 & 5 & 6 & 7 \\
\hline $\begin{array}{l}\text { e) Konfirmasi pembayaran dikirim melalui beberapa metode } \\
\text { seperti Email, untuk verifikasi pembayaran. }\end{array}$ & 1 & 2 & 3 & 4 & 5 & 6 & 7 \\
\hline Q2 - Transaction Procedures & $\begin{array}{c}\text { Sangat } \\
\text { tidak } \\
\text { setuju }\end{array}$ & $\begin{array}{l}\text { Tidak } \\
\text { setuju }\end{array}$ & $\begin{array}{l}\text { Kuran } \\
\text { g } \\
\text { setuju }\end{array}$ & $\begin{array}{c}\text { Tidak } \\
\text { keduan } \\
\text { ya }\end{array}$ & $\begin{array}{l}\text { Agak } \\
\text { setuju }\end{array}$ & Setuju & $\begin{array}{l}\text { Sangat } \\
\text { setuju }\end{array}$ \\
\hline $\begin{array}{l}\text { a) Informasi pribadi Anda yang didaftarkan pada OVO } \\
\text { selalu aman dari pencurian. }\end{array}$ & 1 & 2 & 3 & 4 & 5 & 6 & 7 \\
\hline $\begin{array}{l}\text { b) Informasi pribadi Anda tidak pernah diberikan kepada } \\
\text { pihak ketiga lainnya oleh OVO untuk tujuan apapun. }\end{array}$ & 1 & 2 & 3 & 4 & 5 & 6 & 7 \\
\hline $\begin{array}{l}\text { c) Jumlah pembayaran atau data transaksi yang ditampilkan } \\
\text { pada OVO selalu tepat. }\end{array}$ & 1 & 2 & 3 & 4 & 5 & 6 & 7 \\
\hline $\begin{array}{l}\text { d) Anda merasa, transaksi dengan OVO yang ditransfer } \\
\text { melalui internet dilindungi dengan aman. }\end{array}$ & 1 & 2 & 3 & 4 & 5 & 6 & 7 \\
\hline $\begin{array}{l}\text { e) Layanan pembayaran OVO selalu tersedia kapan saja } \\
\text { setiap harinya. }\end{array}$ & 1 & 2 & 3 & 4 & 5 & 6 & 7 \\
\hline $\begin{array}{l}\text { f) Kesalahan sistem yang bersifat sementara atau mendadak } \\
\text { sering kali timbul pada saat melakukan transaksi melalui } \\
\text { OVO. }\end{array}$ & 1 & 2 & 3 & 4 & 5 & 6 & 7 \\
\hline Q3 - Pernyataan Pengamanan & $\begin{array}{c}\text { Sangat } \\
\text { tidak } \\
\text { setuju }\end{array}$ & $\begin{array}{l}\text { Tidak } \\
\text { setuju }\end{array}$ & $\begin{array}{l}\text { Kuran } \\
\text { g } \\
\text { setuju }\end{array}$ & $\begin{array}{c}\text { Tidak } \\
\text { keduan } \\
\text { ya }\end{array}$ & $\begin{array}{l}\text { Agak } \\
\text { setuju }\end{array}$ & Setuju & $\begin{array}{l}\text { Sangat } \\
\text { setuju }\end{array}$ \\
\hline
\end{tabular}




\begin{tabular}{|c|c|c|c|c|c|c|c|}
\hline $\begin{array}{l}\text { a) OVO menawarkan penjelasan yang detail / terperinci } \\
\text { terkait bagaimana mengulas, membatalkan perubahan, } \\
\text { ataupun mencatat suatu pembayaran. }\end{array}$ & 1 & 2 & 3 & 4 & 5 & 6 & 7 \\
\hline $\begin{array}{l}\text { b) OVO menawarkan pernyataan pengamanan pada } \\
\text { kebijakan keamanan, informasi kontak dalam keadaan } \\
\text { darurat, deskripsi teknis dan fungsi-fungsi lainnya pada } \\
\text { layanan OVO. }\end{array}$ & 1 & 2 & 3 & 4 & 5 & 6 & 7 \\
\hline $\begin{array}{l}\text { c) Anda dapat dengan mudah menemukan pernyataan yang } \\
\text { berhubungan dengan keamanan dalam layanan OVO. }\end{array}$ & 1 & 2 & 3 & 4 & 5 & 6 & 7 \\
\hline $\begin{array}{l}\text { d) Informasi terkait keamanan layanan OVO dapat } \\
\text { ditemukan dengan mudah dari bagian FAQ atau bantuan. }\end{array}$ & 1 & 2 & 3 & 4 & 5 & 6 & 7 \\
\hline $\begin{array}{l}\text { e) Pernyataan mengenai keamanan layanan OVO disusun } \\
\text { dengan baik dengan cara yang mudah dimengerti dan } \\
\text { bebas dari kata-kata teknis. }\end{array}$ & 1 & 2 & 3 & 4 & 5 & 6 & 7 \\
\hline $\begin{array}{l}\text { f) Pernyataan mengenai keamanan layanan OVO disusun } \\
\text { dalam kata-kata yang menarik perhatian Anda untuk } \\
\text { membacanya. }\end{array}$ & 1 & 2 & 3 & 4 & 5 & 6 & 7 \\
\hline Q4 - Tingkat Kepercayaan & $\begin{array}{l}\text { Sangat } \\
\text { tidak } \\
\text { setuju }\end{array}$ & $\begin{array}{l}\text { Tidak } \\
\text { setuju }\end{array}$ & $\begin{array}{l}\text { Kuran } \\
\mathrm{g} \\
\text { setuju }\end{array}$ & $\begin{array}{l}\text { Tidak } \\
\text { keduan } \\
\text { ya }\end{array}$ & $\begin{array}{l}\text { Agak } \\
\text { setuju }\end{array}$ & Setuju & $\begin{array}{l}\text { Sangat } \\
\text { setuju }\end{array}$ \\
\hline a) Saya merasa transaksi melalui layanan OVO aman. & 1 & 2 & 3 & 4 & 5 & 6 & 7 \\
\hline $\begin{array}{l}\text { b) Saya memiliki anggapan bahwa informasi yang berkaitan } \\
\text { dengan pengguna dan juga transaksi pada layanan OVO } \\
\text { adalah aman. }\end{array}$ & 1 & 2 & 3 & 4 & 5 & 6 & 7 \\
\hline $\begin{array}{l}\text { c) Informasi yang saya daftarkan di sistem OVO sangat } \\
\text { membantu untuk melakukan transaksi pembayaran yang } \\
\text { aman. }\end{array}$ & 1 & 2 & 3 & 4 & 5 & 6 & 7 \\
\hline $\begin{array}{l}\text { d) Saya tidak khawatir akan adanya serangan peretas } \\
\text { terhadap sistem OVO. }\end{array}$ & 1 & 2 & 3 & 4 & 5 & 6 & 7 \\
\hline Q5 - Tingkat Keamanan & $\begin{array}{c}\text { Sangat } \\
\text { tidak } \\
\text { setuju }\end{array}$ & $\begin{array}{l}\text { Tidak } \\
\text { setuju }\end{array}$ & $\begin{array}{l}\text { Kuran } \\
\text { g } \\
\text { setuju }\end{array}$ & $\begin{array}{c}\text { Tidak } \\
\text { keduan } \\
\text { ya }\end{array}$ & $\begin{array}{l}\text { Agak } \\
\text { setuju }\end{array}$ & Setuju & $\begin{array}{l}\text { Sangat } \\
\text { setuju }\end{array}$ \\
\hline $\begin{array}{l}\text { a) Saya percaya terhadap seluruh partisipan yang terlibat } \\
\text { dalam sistem pembayaran OVO seperti penjual dan } \\
\text { pembeli. }\end{array}$ & 1 & 2 & 3 & 4 & 5 & 6 & 7 \\
\hline $\begin{array}{l}\text { b) Saya percaya akan mekanisme keamanan pada sistem } \\
\text { pembayaran OVO. }\end{array}$ & 1 & 2 & 3 & 4 & 5 & 6 & 7 \\
\hline c) Saya percaya pada layanan sistem pembayaran OVO. & 1 & 2 & 3 & 4 & 5 & 6 & 7 \\
\hline $\begin{array}{l}\text { d) Saya tidak khawatir akan adanya serangan peretas } \\
\text { terhadap sistem OVO. }\end{array}$ & 1 & 2 & 3 & 4 & 5 & 6 & 7 \\
\hline Q6 - Pengalaman Masa Lalu & $\begin{array}{c}\text { Sangat } \\
\text { tidak } \\
\text { setuju }\end{array}$ & $\begin{array}{c}\text { Tidak } \\
\text { setuju }\end{array}$ & $\begin{array}{l}\text { Kuran } \\
\text { g } \\
\text { setuju }\end{array}$ & $\begin{array}{c}\begin{array}{c}\text { Tidak } \\
\text { keduan } \\
\text { ya }\end{array} \\
\end{array}$ & $\begin{array}{c}\text { Agak } \\
\text { setuju }\end{array}$ & Setuju & $\begin{array}{l}\text { Sangat } \\
\text { setuju }\end{array}$ \\
\hline $\begin{array}{l}\text { a) Saya memiliki pengalaman terkait pernah memesan suatu } \\
\text { produk atau layanan dari situs web. }\end{array}$ & 1 & 2 & 3 & 4 & 5 & 6 & 7 \\
\hline $\begin{array}{l}\text { b) Saya pernah melakukan pembayaran pesanan di internet } \\
\text { dengan menggunakan kartu kredit. }\end{array}$ & 1 & 2 & 3 & 4 & 5 & 6 & 7 \\
\hline $\begin{array}{l}\text { c) Saya pernah melakukan pembayaran pesanan di Internet } \\
\text { dengan Sistem Pembayaran Elektronik selain } \\
\text { penggunaan kartu kredit (melalui transfer, PayPal, dll). }\end{array}$ & 1 & 2 & 3 & 4 & 5 & 6 & 7 \\
\hline
\end{tabular}




\begin{tabular}{|c|c|c|c|c|c|c|c|}
\hline $\begin{array}{l}\text { d) Saya sudah cukup lama menggunakan layanan transaksi } \\
\text { online dan sistem pembayaran elektronik. }\end{array}$ & 1 & 2 & 3 & 4 & 5 & 6 & 7 \\
\hline $\begin{array}{l}\text { e) Saya sering mendapatkan manfaat dari sistem pembayaran } \\
\text { online. }\end{array}$ & 1 & 2 & 3 & 4 & 5 & 6 & 7 \\
\hline Q7 - Penggunaan Sistem Pembayaran Elektronik & $\begin{array}{c}\text { Sangat } \\
\text { tidak } \\
\text { setuju }\end{array}$ & $\begin{array}{l}\text { Tidak } \\
\text { setuju }\end{array}$ & $\begin{array}{l}\text { Kuran } \\
\text { g } \\
\text { setuju }\end{array}$ & $\begin{array}{l}\text { Tidak } \\
\text { keduan } \\
\text { ya }\end{array}$ & $\begin{array}{l}\text { Agak } \\
\text { setuju }\end{array}$ & Setuju & $\begin{array}{l}\text { Sangat } \\
\text { setuju }\end{array}$ \\
\hline $\begin{array}{l}\text { a) Saya lebih sering menggunakan OVO daripada } \\
\text { pembayaran yang lainnya. }\end{array}$ & 1 & 2 & 3 & 4 & 5 & 6 & 7 \\
\hline $\begin{array}{l}\text { b) Saat ini saya adalah pengguna OVO dan akan terus } \\
\text { menggunakannya. }\end{array}$ & 1 & 2 & 3 & 4 & 5 & 6 & 7 \\
\hline c) Saya yakin bahwa pengguna OVO akan meningkat. & 1 & 2 & 3 & 4 & 5 & 6 & 7 \\
\hline
\end{tabular}

Q8. Lengkapi pernyataan mengenai Anda di bawah ini: (beri tanda silang (X) pada kotak) a)

Jenis kelamin:

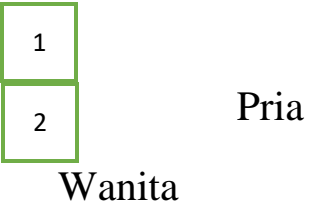

b) Usia:

c) Status:

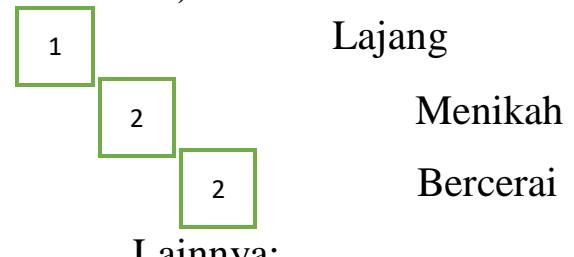

d) Pekerjaan:

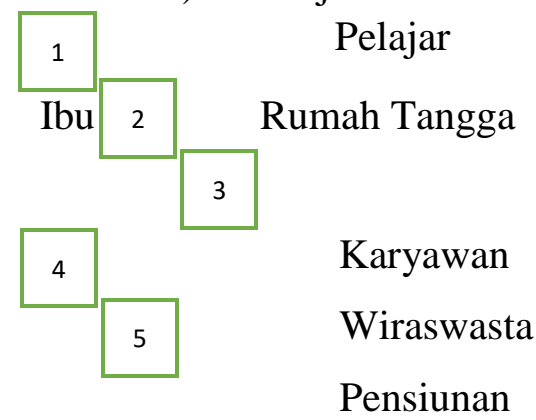

e) Pendidikan terakhir: 


\begin{tabular}{|c|c|}
\hline 2 & SMP \\
\hline 3 & SMA \\
\hline 4 & \\
\hline
\end{tabular}

Diploma

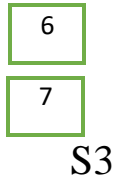

Lainnya:
S2

1

f) Penghasilan per bulan:

< Rp. 3.000 .000

2

$3 \quad$ Rp. 3.000.001 - Rp. 10.000 .000

Rp. 10.000.001 - Rp.30.000.000

4

> Rp. 30.000.001

Terima kasih atas partisipasi Anda 